\title{
Evaluation of bioherbicide for controlling weedy rice and enhancing the yield of rice in Malaysia
}

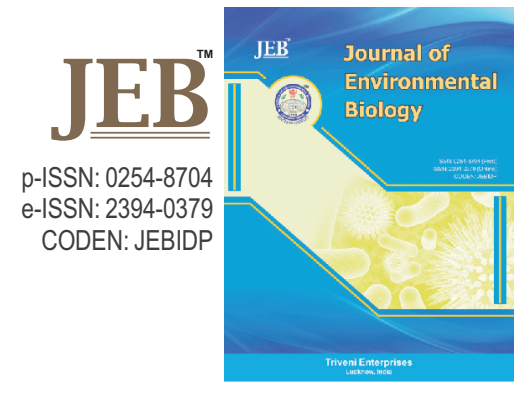

Authors Info

M.A. Hakim ${ }^{1,2}$, A.S. Juraimi ${ }^{3}$, N.B. Khalid ${ }^{3}$ F. Aslani ${ }^{3}$, M.A. Alam ${ }^{4}$, S.M.R. Karim ${ }^{5}$, A.K.M. Mosharof Hossain ${ }^{6}$ and M.S. Islam 'Institute of Tropical Agriculture, Universiti Putra, UPM Serdang, Selangor, 43400, Malaysia

${ }^{2}$ Department of Agricultural Chemistry, Hajee Mohammad Danesh Science and Technology University, Dinajpur, 5200, Bangladesh

${ }^{3}$ Department of Crop Science, Universiti Putra, UPM Serdang, Selangor Darul

Ehsan, 43400, Malaysia

${ }^{4}$ Faculty of Sustainable Agriculture, Horticulture and Landscaping Program, Universiti Malaysia Sabah, Sandakan Campus, Sandakan 90509, Sabah, Malaysia

${ }^{5}$ Faculty of Agro-Based Industry, Universiti Malaysia Kelantan, Campus Jeli, Kelantan, 17600, Malaysia

${ }^{6}$ Department of Soil Science, Hajee Mohammad Danesh Science and Technology University, Dinajpur, 5200, Bangladesh

'Department of Agronomy, Hajee Mohammad Danesh Science and Technology University, Dinajpur, 5200, Bangladesh

${ }^{*}$ Corresponding Author Email : ahakimupm@gmail.com

Key words

Agroplus BioDcomposer

Bioherbicide

Paraquat

Rice yield

Weedy rice

Publication Info

Paper received : 31.05 .2016

Revised received : 12.10 .2016

Re-revised received: 14.01.2018

Accepted: 16.01.2018

\section{Abstract}

Aim : Rice (Oryza sativa L.) is the second most important food crop in Malaysia, and weedy rice is the severe constraint in the Malaysian rice field. An experiment was conducted in Shadehouse at Field 2, Universiti Putra Malaysia to assess the performance of Agroplus BioDcomposer as a bioherbicide to control weedy rice and to select appropriate dosage of Agroplus BioDcomposer for effective control of weedy rice in the rice field.

Methodology : Ten treatments of herbicides were applied in the experiment viz., control ( $0 \mathrm{ml})$, Agroplus BioDcomposer@ (150 ml $20 \mathrm{I}^{-1}$ water, $300 \mathrm{ml}_{20} 20 \mathrm{I}^{-1}$ water and $450 \mathrm{ml}^{2} 2 \mathrm{I}^{-1}$ water), Paraquat (125 ml $20 \mathrm{I}^{-1}$

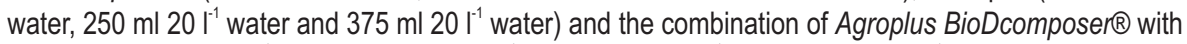
Paraquat @150 ml 20l l- water + @125 ml $20 \mathrm{l}^{-1}$ water, $300 \mathrm{ml}^{2} 2 \mathrm{l}^{-1}$ water + $250 \mathrm{ml} 20 \mathrm{l}^{-1}$ water and $450 \mathrm{ml} 20 \mathrm{l}^{-}$ ${ }^{1}$ water+375 ml $20 \mathrm{I}^{-1}$ water). Data on the percentage of weedy rice killed three days after treatments and percentage of weedy rice emergence 7 and 14 days after soil application of treatments were recorded to evaluate the efficacy of different treatments.

Results : The results revealed significant differences among treatments in the percentage of weedy rice killed, weedy rice emergence after treatments application and the ultimate yield of rice. Paraquat, @ $375 \mathrm{ml}$ $20 \mathrm{I}^{-1}$ water and a combination of Agroplus BioDcomposer ${ }^{\circledR}$ and Paraquat $\left(300 \mathrm{ml}^{2} 2 \mathrm{l}^{-1}\right.$ water $+250 \mathrm{ml} 20 \mathrm{I}^{-1}$ water) performed better over other treatments to kill the weedy rice, to control the emergence of weedy rice from the seed bank and produced the highest rice yield.

Interpretation : The overall result revealed that the recommended rate of Agroplus BioDcomposer $₫+$ Paraquat (300 ml $20 \mathrm{I}^{-1}$ water $+250 \mathrm{ml}^{2} 2 \mathrm{I}^{-1}$ water) is more appropriate and suitable for environmental friendly control of weedy rice in Malaysia.

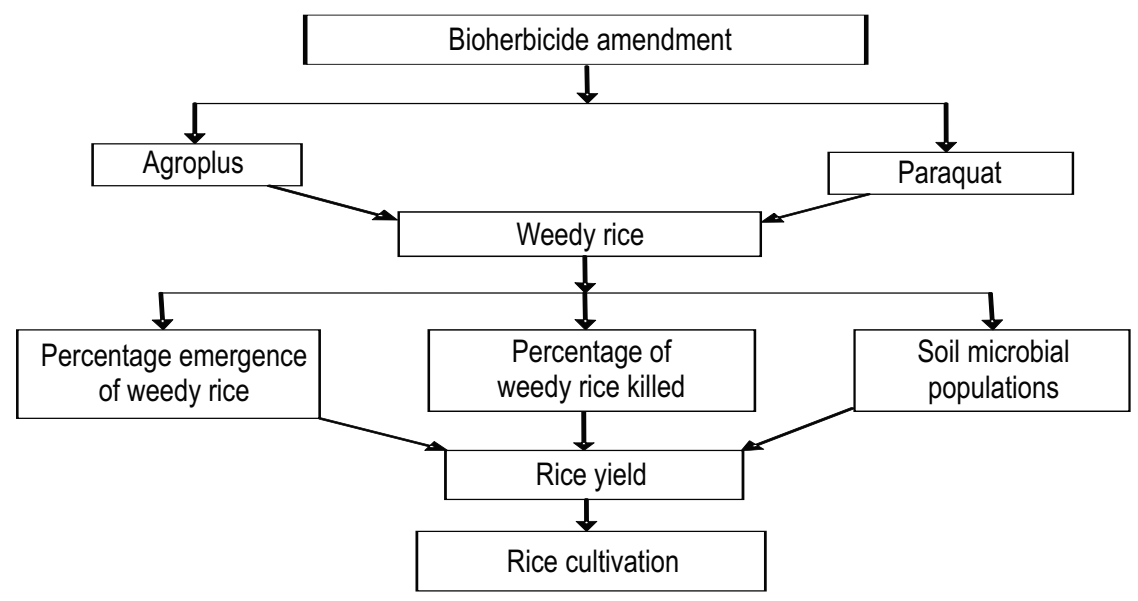




\section{Introduction}

Rice is one of the major cereal crops and staple food for many people of the world including Asia, Latin America and the Caribbean. It is the third most important crop in Malaysia and the total area (including main and offseason) of about 692,600 ha is under rice cultivation (DOA, 2010). Every year rice production in Malaysia is increasing and since 2000 , the production has increased to about 323,927 tons (DOA, 2010).

Worldwide, weed is the most troublesome pest in the rice field. Traditionally, weeds are controlled in transplanted rice and puddle soil by water management and hand weeding (Suwanketnikon, 2000). However, rice farmers in many countries including Malaysia have changed the method of planting from transplanting to direct seeding due to labor shortage. It is difficult to control weeds, especially weedy rice in direct seeding method (Suwanketnikon, 2000). Weedy rice is commonly considered as an ecotype of Oryza sativa and is known as 'padi angin' in Malaysia. They are the progeny of crosses between wild rice and cultivated rice or have resulted from the deprivation of cultivated rice varieties (Chauhan, 2012). The weed invades and severely infests rice fields. The dominant characteristic of weedy rice closely resembles the cultivated rice and the seeds are shattered early. Weedy rice affects rice yield because of its highly competitive capacity. It competes with cultivated rice for light, nutrient, water and space.

The farmers are unable to harvest the grains of weedy rice due to its tendency to mature early and shatter readily, which leads to reduced crop yield. Weedy rice has become a severe threat in several parts of Asia, causing yield loss in rice and increased production cost. In Malaysia, loss in rice yield due to weedy rice infestation has been reported to be $74 \%$ (Chauhan, 2012). Azmi et al. (2005) stated that infestation by thirty-five weedy rice panicles per meter caused a yield loss of about one $t \mathrm{~h}^{-1}$. Controlling weedy rice is essential because weedy rice infestation in rice fields is dangerous as seeds increase over time in seed bank with self-regeneration and there is no appropriate selective herbicide for controlling weedy rice (Chin et al., 2007). Herbicidebased weed management is the most popular way to manage weedy rice; however, the latest invented method is Clearfield Rice Production System (Davis et al., 2011).

Until the release of Imidazolinone-tolerant rice in 2002, no selective herbicide could control the weedy rice in the rice field (Davis et al., 2011). Prolong use of herbicide can cause herbicide resistance of specific weed species, a health hazard to farmers and environmental pollution. To prevent environmental contamination and biomagnification of herbicides, a company named by Duhc Technologies Sdn Bhd has launched an environmentally friendly product named Agroplus BioDcomposer that can rot rice straw and kill weedy rice seeds in soil seed bank. However, the performance of this product is yet to be scientifically investigated. Agroplus BioDcomposer contains a consortium of microbes that can decompose weeds and seedlings. Therefore, there is a need to evaluate the Agroplus product, as well as to develop an appropriate weedy rice management technology in Malaysia and other Southeast Asian countries. Paraquat is a quick-acting and non-selective herbicide killing green plant tissue on contact. However, use of higher dose to kill weedy rice is a bit risky due to its redox activity, which produces superoxide anions (Kamel, 2013). Mixing of this quick-acting herbicide with bioherbicide may reduce the toxicity and increase the activity of Agroplus BioDcomposer bioherbicide. Information on this aspect for controlling weedy rice is not available in Malaysia. In view of the above, the present study was conducted to select the appropriate dose of Agroplus BioDcomposer, Paraquat and combination of two for controlling weedy rice in rice field.

\section{Materials and Methods}

Experimental site : The experiment was conducted at the Shadehouse in Ladang 2, Universiti Putra Malaysia during the period of 2012 to 2013. The temperature and humidity of the shade house was $\pm 34^{\circ} \mathrm{C}$ and $72 \%$, respectively.

Treatments : Different concentration of Agroplus BioDcomposer, Paraquat and their mixtures used as treatments in the study is shown in Table 1. The study was carried out in a complete randomized design in four replication. The herbicides were applied according to treatment specification in each plastic bucket, but only tap water was used as control treatment. The sprayer was calibrated, and all treatments were applied at the spray volume of $500 \mathrm{ml}$. The treatments were applied twenty-one days after planting of weedy rice seeds. After three days of application, the percentage of weedy rice killed was recorded. The soils were mixed and kept for two weeks more to observe the germination of weedy rice after use of herbicides .

Planting materials : Seeds of weedy rice were collected from Tanjung Karang, the largest rice growing area in Selangor, Malaysia.

Soil preparation : Soil for pot experiment was collected from a rice field in Tanjung Karang. It was pulverized, inert materials, visible insect pests and plant debris were removed. The soil was then crushed, mixed thoroughly and dried in the sun. Plastic buckets ( $32 \mathrm{~cm}$ diameter and $37.5 \mathrm{~cm}$ depth) were filled with $12 \mathrm{~kg}$ of prepared soil. The surface of soil was watered daily and kept for three weeks to observe the weedy rice that germinated from the seed banks. Weedy rice plants were then removed and new weedy rice seeds were planted in the buckets.

Seed preparation : Weedy rice seeds were soaked in water for $24 \mathrm{hrs}$. Sixty-four soaked seeds of weedy rice were planted on the soil surface in each plastic bucket and sixty four unsoaked weedy rice seeds were planted at $5 \mathrm{~cm}$ depth from the soil surface in the same bucket.

Data collection : After treatment, the plastic buckets were left for three days, and the percentage of weedy rice killed was recorded 
Table 1 : Treatments used to control weedy rice

\begin{tabular}{lll}
\hline Label & Treatments & $\begin{array}{l}\text { Rate of application } \\
\mathbf{2 0} \mathbf{L}^{-1} \text { water }\end{array}$ \\
\hline T1 & Control (water) & $0 \mathrm{ml}$ \\
T2 & Agroplus BioDcomposer & $150 \mathrm{ml}$ \\
T3 & Agroplus BioDcomposer & $300 \mathrm{ml}$ \\
T4 & Agroplus BioDcomposer & $450 \mathrm{ml}$ \\
T5 & Paraquat & $125 \mathrm{ml}$ \\
T6 & Paraquat & $250 \mathrm{ml}$ \\
T7 & Paraquat & $375 \mathrm{ml}$ \\
T8 & Agroplus BioDcomposer + & $150 \mathrm{ml}+125 \mathrm{ml}$ \\
& Paraquat & $300 \mathrm{ml}+250 \mathrm{ml}$ \\
T9 & Agroplus BioDcomposer + & (recommended) \\
& Paraquat & $450 \mathrm{ml}+375 \mathrm{ml}$ \\
T10 & Agroplus BioDcomposer + & \\
& Paraquat & \\
\hline
\end{tabular}

Means with same letter within column are not significantly different using Student Newman Keuls (SNK) at $p \leq 0.05$

manually. The percentage emergence of weedy rice was also recorded manually 7,14 and 45 days after treatment.

Data analysis : All the collected data were analyzed using Analysis of Variance at $p \leq 0.05$ by SAS version 9.0 and Microsoft Excel. Student - Newman Keuls was used to test significant difference among treatment means.

\section{Results and Discussion}

Percentage of weedy rice killed : The percentage of weedy rice killed three days after treatment is shown in Table 2. Different treatments showed significant effect on the percentage of weedy rice killed. In season I, the highest number (100\%) of weedy rice killed was recorded in $T 7$ followed by T10, while in season II the highest percentage of weedy rice killed was recorded in $\mathrm{T} 7$ and $\mathrm{T} 9$ as compared to other treatments. T7 and T10 contained high amount of Paraquat and Agroplus BioDcomposer than recommended rate $(150 \%$ of recommended dose). The recommended rate of Paraquat (T6) and combined treatment of Paraquat and Agroplus BioDcomposer (T9) showed $90 \%$ and $95 \%$ performance in killing weedy rice in season I, however, T9 performed better in season II. The higher dose of Paraquat (T7) and combined treatment of Paraquat and Agroplus BioDcomposer (T10) showed $100 \%$ and $98 \%$ performance in season I and $99.35 \%$ and $98.52 \%$ in season II, respectively (Table 2). During both the seasons, no weedy rice was killed in the control treatment (T1) and also in all the individual Agroplus BioDcomposer treatments (T2, T3, and T4). The results indicate that the percentage of weedy rice killed was higher in all the treatments of Paraquat as compared to all the combined treatments of Agroplus BioDcomposer and Paraquat (Table 2). However, considering environmental safety, the combined application of Agroplus BioDcomposer and Paraquat at the rate of

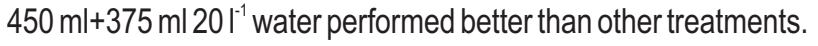

Table 2 : Percentage of weedy rice killed three days after treatment

\begin{tabular}{lll}
\hline & \multicolumn{2}{c}{ Weedy rice killed (\%) } \\
\cline { 2 - 3 } Treatments & Season I & Season II \\
\hline T1 & $0.00^{\mathrm{f}}$ & $0.00^{\mathrm{d}}$ \\
T2 & $0.00^{\mathrm{f}}$ & $0.00^{\mathrm{d}}$ \\
T3 & $0.00^{\mathrm{f}}$ & $0.00^{\mathrm{d}}$ \\
T4 & $0.00^{\mathrm{f}}$ & $0.00^{\mathrm{d}}$ \\
T5 & $90.00^{\mathrm{d}}$ & $92.50^{\mathrm{b}}$ \\
T6 & $95.00^{\mathrm{c}}$ & $92.25^{\mathrm{b}}$ \\
T7 & $100.00^{\mathrm{a}}$ & $99.35^{\mathrm{a}}$ \\
T8 & $80.00^{\mathrm{a}}$ & $85.20^{\mathrm{c}}$ \\
T9 & $97.75^{\mathrm{b}}$ & $98.52^{\mathrm{a}}$ \\
T10 & $98.00^{\mathrm{b}}$ & $98.86^{\mathrm{a}}$ \\
\hline
\end{tabular}

Means with same letter within column are not significantly different using Student Newman Keuls (SNK) at $p \leq 0.05$

Percentage emergence of weedy rice at seven days after treatment: The percentage emergence of weedy rice was noted seven days after treatment. There was significant difference ( $p \leq$ 0.05 ) between the treatments for emergence of weedy rice as shown in Fig. 1. The highest percent emergence of weedy rice $(31.25 \%)$ was recorded in $\mathrm{T} 1$ (control) in season I and $28.50 \%$ in season II, followed by T4 (27.15\%) in season I and (25.85\%) in season II, respectively. The perusal of data reveals that Agroplus BioDcomposerenhanced seed emergence and also plant growth.

The lowest percentage emergence of weedy rice was observed in $\mathrm{T7}(5.85 \%$ and $4.75 \%)$ during both the seasons, followed by T9 $(6 \%$ and $4.95 \%)$. In season I, the third lowest percentage emergence of weedy rice was found in treatment T10 (8.59\%) followed by T6 $(9.55 \%)$, T8 (10.55\%), however in season II T10 (5.75\%), T8 (8.5\%) and T6 (10\%), respectively. The perusal of data indicate that the safety point of view of environment, the treatment T9 was most suitable due to low concentration of paraquat was used in this combined treatment (Fig. 1).

Percentage emergence of weedy rice 14 days after treatments application : After 14 days, the number of weedy rice emergence was recorded for the second time. There was significant difference $(p \leq 0.05)$ between the treatments for percentage emergence of weedy rice as shown in Fig. 2. The highest percent emergence of weedy rice (46.10\%) was observed in T1 (control) followed by T4, $(36.85 \%)$ in season I, however, in season II, the highest percentage emergence of weedy rice was observed in T1 (39\%) followed by $\mathrm{T} 4(33.50 \%)$.

The lowest percentage emergence of weedy rice 14 days after treatment was observed in $\mathrm{T} 7$ followed by $\mathrm{T} 9, \mathrm{~T} 6$ and T10 during both the seasons. It is clear that the two treatments (T7 and T9) performed better over control weedy rice emergence, but T9 was more suitable and environmentally 
friendly as the concentration of Paraquat was low in T9 as compared to $T 7$.

Percentage emergence of weedy rice 45 days after planting rice seeds : Significant differences $(p \leq 0.05)$ among the treatments were also observed for percentage emergence of weedy rice (Fig. 3). The highest percent emergence of weedy rice was recorded in the season I (11.6\%) and Season II (9.5\%) in T1. The second highest percentage emergence of weedy rice was found in $\mathrm{T} 6(7.5 \%)$ in season I and T5 (7.52\%) in season II, respectively.

The lowest percent emergence of weedy rice 45 days after treatment was observed in T9 during both the seasons ( 0 and
$0.25 \%)$. The second lowest percentage emergence of weedy rice $(0.25$ and $0.5 \%$ ) was found in treatment $\mathrm{T} 10$ in season I and season II. The result indicated that $\mathrm{T} 9$ and $\mathrm{T} 1$ showed better performance in controlling weedy rice emergence, but T9 was more suitable and environmentally friendly due to low concentration of Paraquat in the combined treatment, which also reduced the economic loss. The brief description of the overall experimental procedure with output from beginning up to 45 days after planting rice seeds for the recommended solution is shown in Fig. 4.

Microbial population : Difference among the microbial population is shown in Table 3 . The highest population $\left(5 \times 10^{8} \mathrm{CFU} \mathrm{g}^{-1}\right.$ soil) found in T9 followed by T8. The lowest population $\left(1 \times 106 \mathrm{CFU} \mathrm{g}^{-1}\right.$

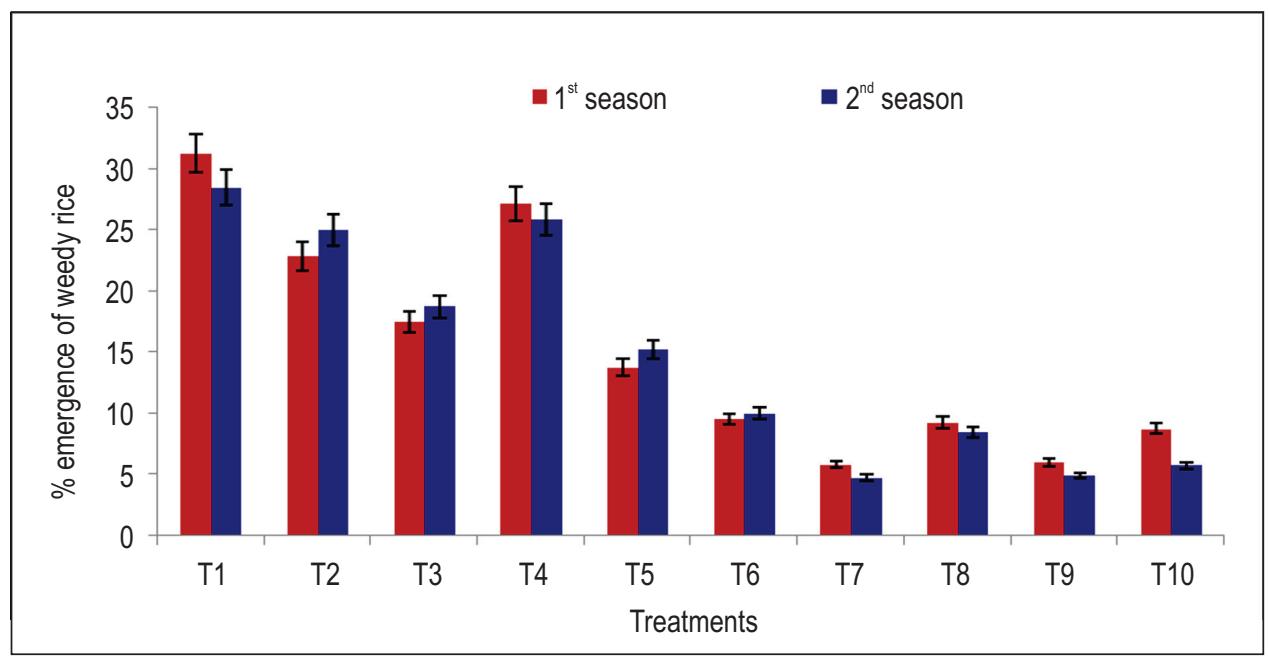

Fig. 1 : Percentage emergence of weedy rice 7 days after treatments. Means with same letter within column are not significantly different using Student Newman Keuls (SNK) at $\mathbf{5} 0.05$

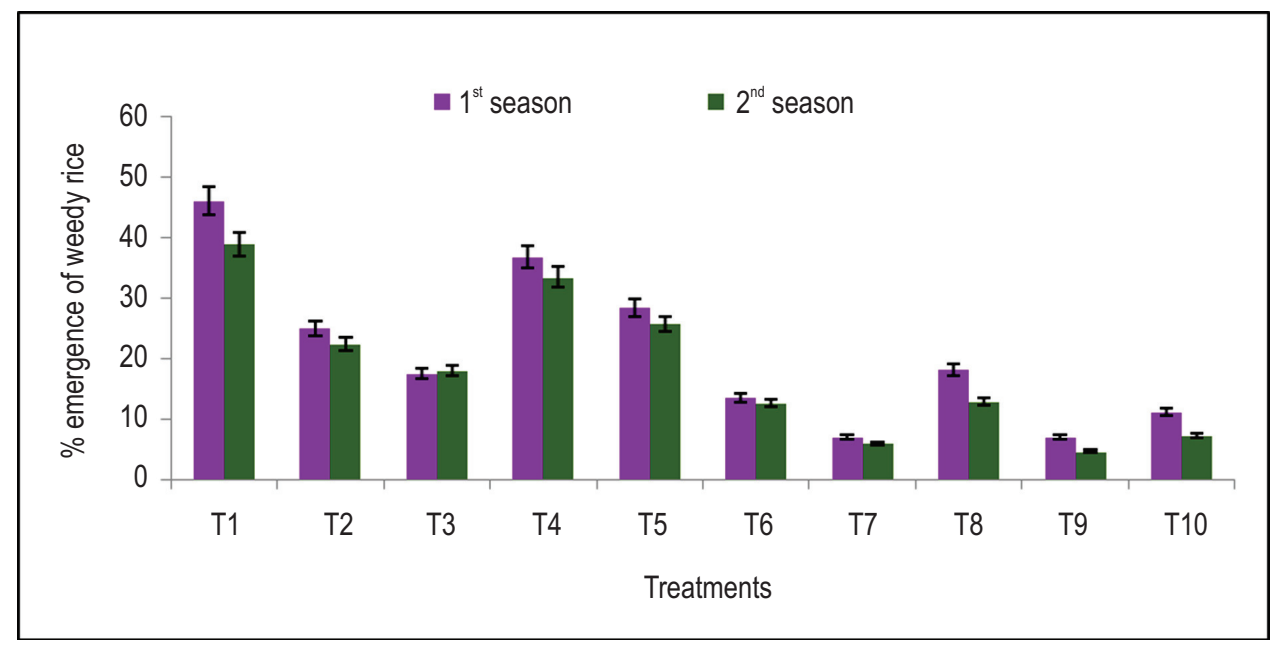

Fig. 2 : Percentage emergence of weedy rice 14 days after treatments. Means with same letter within column are not significantly different using Student Newman Keuls (SNK) at $p \leq 0.05$ 


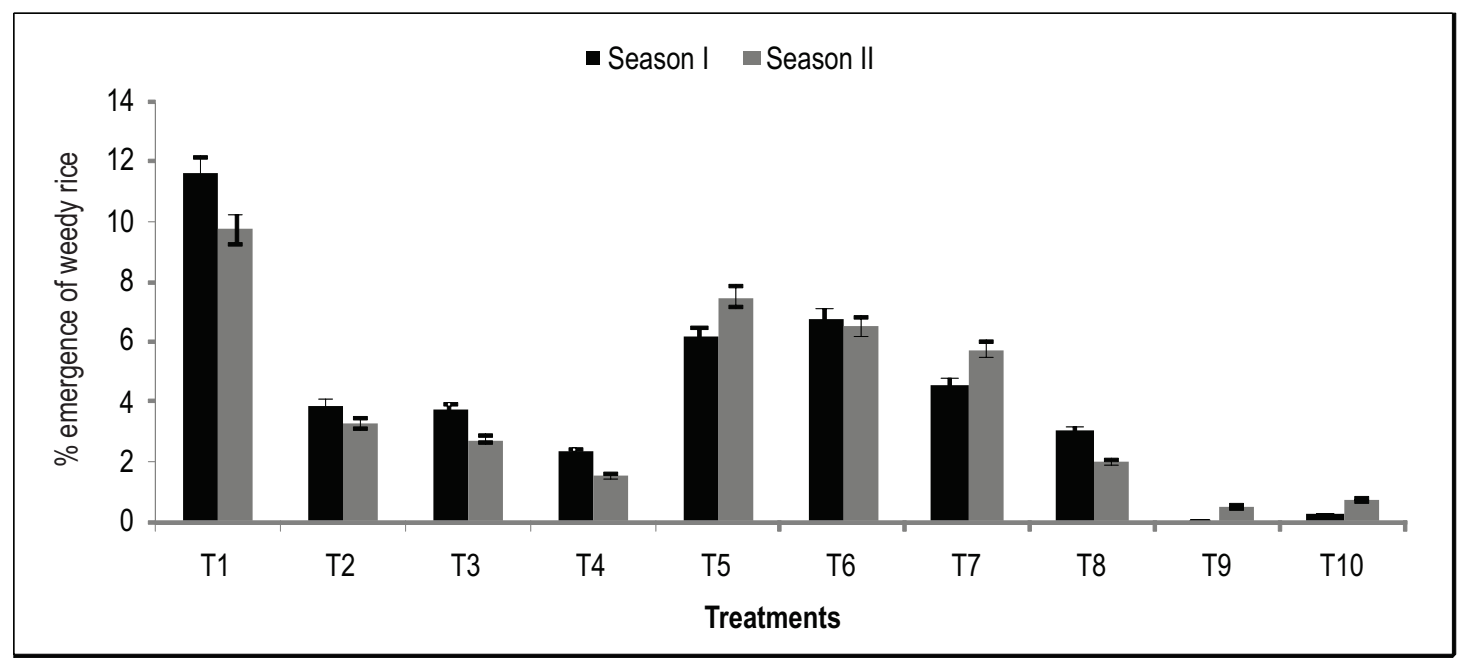

Fig. 3 : Percentage emergence of weedy rice 45 days after treatment. Means with same letter within column are not significantly different using Student Newman Keuls (SNK) at $\mathbf{p} \leq 0.05$

soil) was observed in T1 treatment followed by all the individual treatments of paraquat (Table 3). The Agroplus treatment contained more population than control and all the paraquat treatments, but less population over the combined treatments of Paraquat + Agroplus BioDcomposer. The results indicated that Agroplus enhanced the growth of microbial population.

Rice yield : The difference among different treatments for yield of rice is shown in Table 4. The highest yield $\left(11.55 \mathrm{t} \mathrm{ha}^{-1}\right)$ was found in T9 followed by T10. The lowest yield $\left(7.25 \mathrm{t} \mathrm{ha}^{-1}\right)$ observed in control treatment followed by T5 (Table 4). The results indicate that Agroplus treatment enhanced rice growth that resulted in high yield than control. Weedy rice is a significant weed in directseeded rice that causes about $80 \%$ yield loss and reduction in grain quality. Chauhan (2012) reported rice yield loss of about $74 \%$ in Malaysia due to weedy rice infestation. Most farmers in Malaysia are presently using herbicides as a useful tool in controlling weedy rice (Karim et al., 2004). Manual weeding can also be opted but is not practicable due to high cost and unavailability of labor. In this situation, herbicide is the most

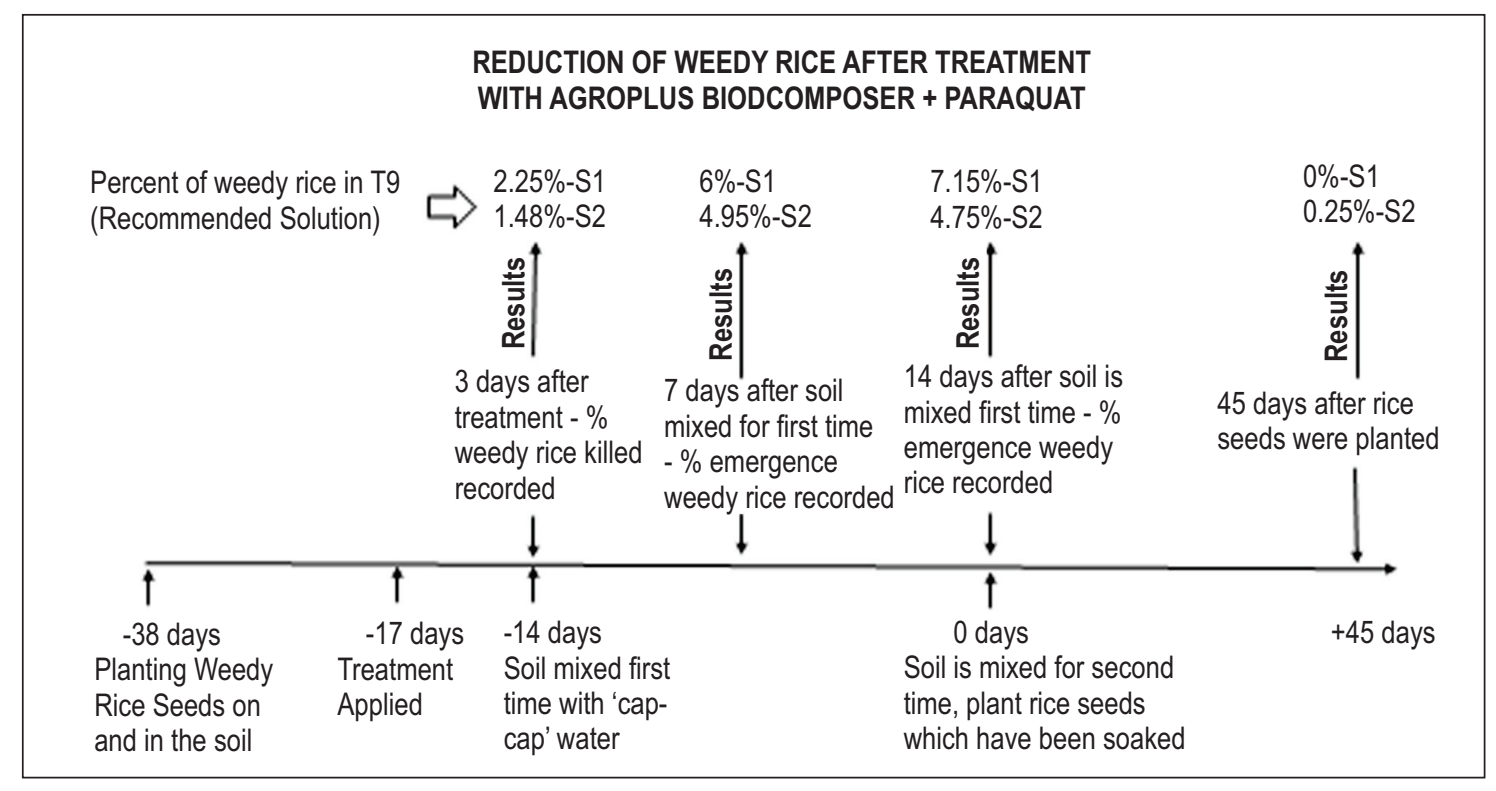

Fig. 4 : Schematic diagram of reduction of weedy rice after treatment with Agroplus BioDcomposer + Paraquat 
Table 3 : Presence of microbes in different treatments

\begin{tabular}{|c|c|c|}
\hline & Treatments & $\begin{array}{l}\text { Microbial } \\
\text { population } \\
\text { (CFUg }\end{array}$ \\
\hline T1 & Control (Water) & $1 \times 10^{6}$ \\
\hline $\mathrm{T} 2$ & $150 \mathrm{ml} 20 \mathrm{~L}^{-1}$ water (Agroplus BioDcomposer) & $3 \times 10^{6}$ \\
\hline T3 & T3300 ml $20 \mathrm{~L}^{-1}$ water (Agroplus BioDcomposer) & $2.5 \times 10^{6}$ \\
\hline T4 & 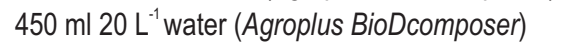 & $3 \times 10^{7}$ \\
\hline $\mathrm{T} 5$ & $125 \mathrm{ml} 20 \mathrm{~L}^{-1}$ water (Paraquat) & $1 \times 10^{8}$ \\
\hline T6 & $250{\mathrm{ml} 20 \mathrm{~L}^{-1} \text { water (Paraquat) }}$ & $1 \times 10^{7}$ \\
\hline $\mathrm{T} 7$ & $\begin{array}{l}375 \mathrm{ml} 20 \mathrm{~L}^{-1} \text { water (Paraquat) } \\
150 \mathrm{ml}+125 \mathrm{ml} 20 \mathrm{~L}^{-1} \text { water }\end{array}$ & $1 \times 10^{7}$ \\
\hline T8 & $\begin{array}{l}\text { (Agroplus BioDcomposer+Paraquat) } \\
300 \mathrm{ml}+250{\mathrm{ml} 20 \mathrm{~L}^{-1} \text { water }}^{\text {w }}\end{array}$ & $5 \times 10^{7}$ \\
\hline T9 & $\begin{array}{l}\text { (Agroplus BioDcomposer+Paraquat) } \\
450 \mathrm{ml}+375{\mathrm{ml} 20 \mathrm{~L}^{-1} \text { water }}^{\text {a }}\end{array}$ & $5 \times 10^{8}$ \\
\hline T10 & (Agroplus BioDcomposer+Paraquat) & $3 \times 10^{8}$ \\
\hline
\end{tabular}

Means with same letter within column are not significantly different using Student Newman Keuls (SNK) at $p \leq 0.05$

practical, efficient and economical means of weed control in rice (Jaya Suria et al., 2011). Paraquat herbicide has played an essential role in improving agricultural production in many countries of the world (Bromilow, 2003). However, as Paraquat is highly poisonous, it must be handled carefully and is recommended to be used in minimum quantity.

Environmental risk of Paraquat include contamination of groundwater, effect on soil organisms and other wildlife, toxicity to aquatic life (Bromilow, 2003). According to Bromilow (2003), Paraquat has been described as a chemical flame gun it killed the above-ground parts of plants while not damaging the roots. The Agroplus BioDcomposer is environmentally friendly because the burning of rice straw in the field can stop by using this product. It is harmless to human health as this product originated from organic sources (DUHC Technologies Sdn Bhd, 2011). Moreover, the cost of labor and herbicide can be reduced as the treatment causes rottening of rice straw. In the present study, Agroplus BioDcomposer not only killed the weedy rice but also enhanced the growth of rice plant.

All the individual doses of Paraquat killed higher percentage of weedy rice as compared to other treatments. The recommended combined dose of Paraquat and Agroplus was found to kill highest number of weedy rice in both seasons, but it performed better in season II. Chin et al. (2007) reported that 95\% of weedy rice was controlled by applying combined doses of herbicides in the Experimental Farm of Cuulong Delta Rice Research Institute (CLRRI), Vietnam.

The percentage emergence of weedy rice was observed 7 and 14 days after treatment in the present study. The overall result revealed that treatment $\mathrm{T} 9$ and $\mathrm{T} 8$ significantly inhibited the emergence of weedy rice seeds,
Table 4 : Rice yield under different treatments

\begin{tabular}{lll}
\hline & \multicolumn{2}{c}{ Rice yields $\left(\mathrm{t} \mathrm{ha}^{-1}\right)$} \\
\cline { 2 - 3 } Treatments & Season I & Season II \\
\hline T1 & $5.21^{\mathrm{e}}$ & $4.54^{\mathrm{f}}$ \\
T2 & $9.41^{\text {cd }}$ & $8.97^{\mathrm{e}}$ \\
T3 & $10.15^{\mathrm{b}}$ & $9.59^{\text {cd }}$ \\
T4 & $9.25^{\text {cd }}$ & $9.56^{\text {cd }}$ \\
T5 & $8.85^{\mathrm{d}}$ & $9.05^{\mathrm{e}}$ \\
T6 & $9.6^{\mathrm{c}}$ & $9.0^{\mathrm{e}}$ \\
T7 & $9.85^{\mathrm{c}}$ & $8.98^{\mathrm{e}}$ \\
T8 & $10.12^{\mathrm{b}}$ & $9.95^{\mathrm{c}}$ \\
T9 & $11.41^{\mathrm{a}}$ & $11.85^{\mathrm{a}}$ \\
T10 & $10.89^{\mathrm{ab}}$ & $11.21^{\mathrm{b}}$ \\
\hline
\end{tabular}

Means with same letter within column are not significantly different using Student Newman Keuls (SNK) at $p \leq 0.05$

probably due to Agroplus enhanced the microbial population that inhibited the germination rate of weedy rice seeds by decomposing the seed bank. The study also indicates that Agroplus treatment did not change the soil microbial population and performed better when used at recommended dose $(300 \mathrm{ml}$

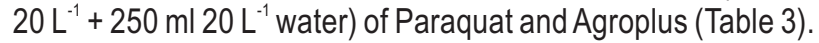
Most of the tested microbial community inhibited germination of weedy rice (Olson et al., 1984). Maneechote et al. (2007) found that a single application of herbicides was not enough for complete control of weedy rice.

From the overall results, the farmers can select the treatment of $\mathrm{T} 9$ for an environmentally friendly control of weedy rice seeds. Young et al. (1984) observed that germination of grass weeds was delayed due to treatment of Paraquat and other herbicides. The results of the present study is consistent with the findings of Nimanthika and Weerakoon (2012) and Nasimul Bari (2010) who observed that use of butachlor herbicide improved the growth of rice plants. Weed management, especially in weedy rice is a fundamental practice in rice cultivation (Begum et al., 2008).

The study concludes that for effective control of weedy

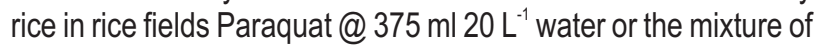

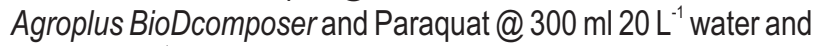

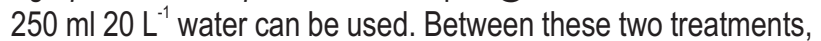
the second treatment is better recommended for killing the weedy rice in Malaysian rice field because the second treatment is more eco-friendly than the first one.

\section{References}

Azmi, M., H. Muhammad and D.E. Johnson : Impact of weedy rice infestation on rice yield and influence of crop establishment technique. The $20^{\text {th }}$ Asian-Pacific Weed Science Society Conference, Ho Chi Minh, pp. 507-513 (2005).

Begum, M., A. S. Juraimi, S. R. Syed Omar, A. Rajan and M. Azmi : Effect 
of herbicide for the control of Fimbristylis miliacea (L.) Vahl. in rice. J.Agronomy, 7, 251-257 (2008).

Bromilow, R. H. : Paraquat and sustainable agriculture. Pest Manag. Sci., 60, 340-349 (2003).

Chauhan, B. : Weedy rice (Oryza sativa) II. response of weedy rice to seed burial and flooding depth. Weed Science Society of America, 60, 385-388 (2012).

Chin, D.V., T.C. Thien, H. H. Bi and N. T. Nhiem : Study on weed and weedy rice control by Imidazolinone herbicides in Clearfield ${ }^{\mathrm{TM}}$ paddy grown by Imi-Tolerance Indica rice variety. Omonrice, 15, 63-67 (2007).

Davis, B.M., R. C. Scott and J.W. Dickson : Rotational options for reducing red rice (Oryza sativa) in clearfield rice production systems. AAES Research /B.R. Wells Rice Research Studies, 60, 155-160 (2011).

DOA : Laporan penyiasatan pengeluaran padi, luar musim 2010. Jabatan Pertanian Malaysia (2010).

DUHC Technologies Sdn Bhd. : Agroplus : Kembali kepada fitrah. Retrieved February 28, 2013, from http:// agroplus4u.com.my (2011).

Jaya Suria, A.S.M., A.S. Juraimi, M. M. Rahman, A. Man and A. Selamat: Efficacy and economics of different herbicides in aerobic rice system. African J. Biotech., 10, 8007 - 8022 (2011).

Kamel, F. : Paths from Pesticides to Parkinson's. Science, 341, 722-723 (2013).

Karim, S. M. R. : Weed problems and their management in rice fields of Malaysia :An overview. Weed Biol. Manag., 4, 177-186 (2004).

Maneechote, C., S. Jiaranairungroj, J. Areerat, J. Supapol and S. Jamjod: Weed Wiper: An innovative method for controlling weedy rice (Oryza sativa) in rice fields. The $21^{\text {st }}$ Asian Pacific Weed Science Society Conference, Sri Lanka, pp. 280-284 (2007).

Nasimul Bari, M.: Effects of the herbicides on weed suppression and rice yield transplanted on wetland rice. Weed Sci Res., 16, 349-361 (2010).

Nimanthika, W.J. and S.R. Weerakoon : Impact of pre and post planting herbicides on growth performance and yield of Oryza genotypes in Sri Lanka. Weed Sci. Res., 18, 469-475 (2012).

Olson, P., D.A. Yuen and D. Balsiger: Mixing of passive heterogeneities by mantle convection. J. Geophy. Res., 89, 425-436(1984).

Suwanketnikon, R.: Opening address. Wild and weedy rice in rice ecosystem in Asia-Areview. Los Banos : IRRI (2000).

Young, F.L., D.R Gealy and L. A. Morrow: Effect of herbicides on germination and growth of four grass weeds. Weed Science, 32 , 489-493 (1984). 